\title{
LEJTŐK ÉS CSÚSZDÁK, AVAGY A FOGLALKOZ- TATÁSI ESÉLYEK TÉRBELI EGYENLŐTLENSÉGE AZ EZREDFORDULÓN
}

\author{
(Slopes and Slides: Spatial Inequalities in Employment \\ Opportunities at the Turn of the Millenium)
}

\section{BIHARI ZSUZSANNA - KOVÁCS KATALIN ${ }^{1}$}

Kulcsszavak:

foglalkoztatás munkanélküliség területi szegregáció integrált terek és perifériák településkategóriák és kistérség típusok

A tanulmány a kilencvenes években ható térformáló erōkkel és a nyomukban létrejövö tértípusokkal foglalkozik. Az elsö rész a népességnagyság és telepiulési státusz (város vagy község) alapján képzett telepillés-kategóriák târsadalomszerkezetét, képzettségi és foglalkoztatási struktúráját tárgyalja. A második rész a kistérségi tipológiát allít fel, éspedig a kistérségi központok dinamizáló, térszervezó ereje, foglalkoztatási képessége alapján. A szerzök azt a következtetést vonják le, hogy továbbra is a foldrajzi helyzet, a magterületektöl és dinamikus központoktól való távolság az, amely meghatározza az egyes téregységek integrált vagy periférikus jellegét, abszorpciós képességét, következésképpen foglalkoztatási kapacitásait.

\section{Bevezetés}

Tanulmányunkban arra vállalkoztunk, hogy elemezzük a rendszerváltozás óta markánsan megmutatkozó térbeli folyamatokat, a hangsúlyt ezúttal a foglalkoztatás kérdéskörére helyezve. ${ }^{2}$ Elemzéseink népességnagyság, illetve a 2004. januárjától érvényes statisztikai kistérségek szerint aggregált települési adatbázison alapulnak, így mind a falvak, azon belül is az aprófalvas térségek világában, mind pedig a dinamikus térségekben, fóképpen a metropolisz övezetben és annak egyre távolabbra nyúló hatókörében megmutatkozó folyamatokat átfogják. Ha úgy tetszik, érintik azoknak a problémaköröknek meglehetősen széles spektrumát, amelyekkel Enyedi György pályafutása során behatóan foglalkozott.

A magyar település-állomány bármelyik elemét vizsgálva, Enyedi választ keresett arra a kérdésre, hogy elemzésének tárgya mennyiben mutat rokonságot a világban zajló folyamatokkal, esetleg mennyiben képezi azoknak részét. Így van ez jelen tanulmány témaköreit és az elemzésekböl levont következtetéseket illetően is, amelyek jórészt igazolják Enyedi azon negyedszázada közzétett megállapításait, amelyeket a falvak jövőjével, illetve a térszervezỏdés várható alakulásával kapcsolatban megfogalmazott. Itt elsősorban azon tételére gondolunk, hogy t.i. a falu és város közötti különbségek elmosódnak, alapvetö különbség a dinamikusan fejlödö és a hanyatló falusias térségek, nem annyira falu és város között rajzolódik ki ${ }^{3}$. 
Írásunk első fejezetében foglaltak, ahol a népességszám szerint képzett telepuiléskategóriák alapján vizsgáltuk a falvak társadalomszerkezetéről valló mutatószámokat, látszólag ellentmondanak ennek, mert még mindig szoros összefüggést találtunk a településnagyság és a helyi társadalmak összetétele, az ott élök képzettsége, jövedelmi viszonyai és foglalkoztathatósága/elhelyezkedési esélyei között. Vagyis a huszadik század utolsó évtizedének statisztikai adatai még mindig a városok és falvak között, sőt, a falvak különböző kategóriái között meghúzódó, mélyreható különbségeket látszanak bizonyítani az ott élők életkilátásai, karrier-lehetőségei stb. tekintetében. Az ellentmondás mégis látszólagos, mert eredményeink mögött a periférikus elhelyezkedésủ kistelepüléseken élök helyzetének drámai méreteket öltő romlása munkál, amelyet nem tudtak kiegyensúlyozni azoknak a dinamikus térségekben elhelyezkedö, integrált aprófalvas térségeknek a kedvezőbb mutatói, amelyek pedig éppen Enyedi megállapításainak igazságát támasztják alá.

Tanulmányunk második része, amelyben kistérségi szinten vizsgáltuk a központi funkciókat betöltö települések hatókörét, integráló erejét és a foglalkoztatásban, népességnövekményben, korszerkezetben és más tényezőkben megmutatkozó dinamizmust vagy éppen annak ellentettjét, a hanyatlást, azt találtuk, amit Enyedi György korabeli nyugat-európai és észak-amerikai minták alapján elöre vetített. Azt ugyanis, hogy a települések földrajzi elhelyezkedése, a dinamikus központoktól mért távolsága, ill. a központok megközelithetösége határozza meg az ott élök jelenlegi pozícióit és jövőbeli kilátásait.

Korábbi empirikus vizsgálataink is megerösítették, hogy nem egyszerủen a (nagy)városi gazdaságok, város-együttesek gazdasági ereje indukálta a falvak helyzetét meghatározó térszervező folyamatokat, amelyek legalábbis hangsúlyeltolódást idéztek elő a korábbiakhoz képest, s napjainkban nyugat-európai kottára formálják át a magyar településhálózatot ${ }^{4}$. A falut, mint a városi gazdaságok által integrált lakóhelyet és rekreációs színteret választók, továbbá a városból olcsóbb megélhetési lehetöségért falura menekülők költözései, összességében a településkategóriák közötti új munkamegosztás legalább akkora szerepet játszott a pólusok formálódásában, a szuburb övezetek kialakulásában, egyrészt, és a hátrányos helyzetủ társadalmi rétegek perifériákon történö tömörülésében, másrészt, mint a városok foglalkoztatási kapacitása.

A falu új vagy új hangsúlyt kapó funkciói tehát - lakóhely, üdülőhely, a tájgondozás színtere - amelyek az évezred végére az Európai Unió vidékpolitikáját befolyásoló paradigmává izmosultak ${ }^{5}$ a rendszerváltozás után, markáns migrációs mozgást indukálva, hazánkban is teret nyertek, amiként tanulmányunk azt több ponton illusztrálja. 


\section{A lejtön: a térbeli folyamatok tükrözödése és a foglalkoztatási esélyek eltérö településkategóriákban}

Amikor e szempont vizsgálata mellett döntöttünk, kérdésünk az volt, hogy vajon a rendszerváltás óta felerősödő folyamatok - v.ö. növekvô területi egyenlötlenségek, a nagyvárosokból a falvak felé irányuló pozitív vándorlási egyenleg - mellett is fennmaradt-e a települési lejtő müködésében tapasztalható, a megelőző mintegy négy évtizedre oly jellemző kíméletlen következetesség? ${ }^{6}$ Vajon manapság is biztosra vehetö-e, hogy nagyobb az esélye a foglalkoztatásra, a magasabb jövedelmek megszerzésére, a komfortosabb életvitel megteremtésére annak az állampolgárnak, aki népesebb községben él, mint annak, aki kisebben; a nagyobb város lakója helyzeti elönyt élvez-e kisvárosi polgártársával szemben; több eséllyel indul-e még ma is a városlakó a falusi honpolgárhoz képest? Nos, a feltett kérdésre a válaszunk: igen. Mert bár a változás jelei szórványosan érzékelhetőek, összességében nem mutatható ki áttörés a települési lejtö, a településnagyság perdöntő hatása tekintetében. Hiába a nagymértékủ lakóhelyi szuburbanizáció ${ }^{7}$ föként a metropolisz régióban és a regionális központok körül, vagy a nagyon is eltérő fejlődési irányok az aprófalvas régiók között, a népességnagyság alapján alkotott településkategóriák szerinti aggregátumokban ezeknek a tendenciáknak csupán halvány jelei mutatkoznak.

Melyek tehát a "települési lejtó szabályszerü" mủködésének megnyilvánulásai? Az egyik első és legfontosabb sajátossága, hogy összességében folytatódik a kistelepiulések demográfiai eróziója, vagyis továbbra is a kisfalvakban a legkedvezőtlenebb a népesség korszerkezete, nagymértékú az elöregedés, a legkisebbekből még mindig többen vándorolnak el, mint ahányan érkeznek, és hiába pozitív a nagyobbacska falvak többségének vándorlási egyenlege, az elöregedés, az alacsony gyermekszám a lakosság számának folyamatos csökkenését eredményezi. Ennek következtében nö a kistelepülések száma, a legkisebb törpefalvaké is, bár a bennük élök száma csökken. Pedig az itt adózók számának két százalékos emelkedéséből arra következtethetünk, hogy a beköltözők között többségben vannak a gazdaságilag aktív jövevények. Ezzel állhat összefüggésben, hogy bár a legkisebb településeken élö foglalkoztatottak átlagjövedelme a legalacsonyabb, a különbség ebben a tekintetben nem nỏtt, hanem valamelyest csökkent 1994 és 2001 között, a budapestiek adatait nem tartalmazó átlag 76,4\%-ról 77,5\%-ra (1. táblázat).

Ez azt mutatja, hogy a mégoly markáns, új, illetve széttartó tendenciákat is eltakarja a fősodor: a nagyobb falvak magas vándorlási nyeresége, az ebből következő népességgyarapodás, továbbá az adózók számában bekövetkező jelentős növekmény a városiak és a falusiak beköltözéseinek hatását egyaránt tükrözi; az ötezer fösnél népesebbekben kifejezetten felülreprezentáltak a városkörnyéki, rendre városi rangra áhítozó községek. 
(\%) $u m q p(m), \mathrm{N}$

sassadan sana to

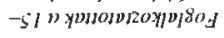

(of) Nowjzoy) ont Dunojmroyp

youpm!ws

yaxjoljpymma $V$

y

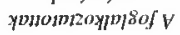

(\%) Mnqp(m⿻上丨 yonomizoylmisof p ozo8jop nadjayoxy

\% xpanta opd lomint majapan of OHaN

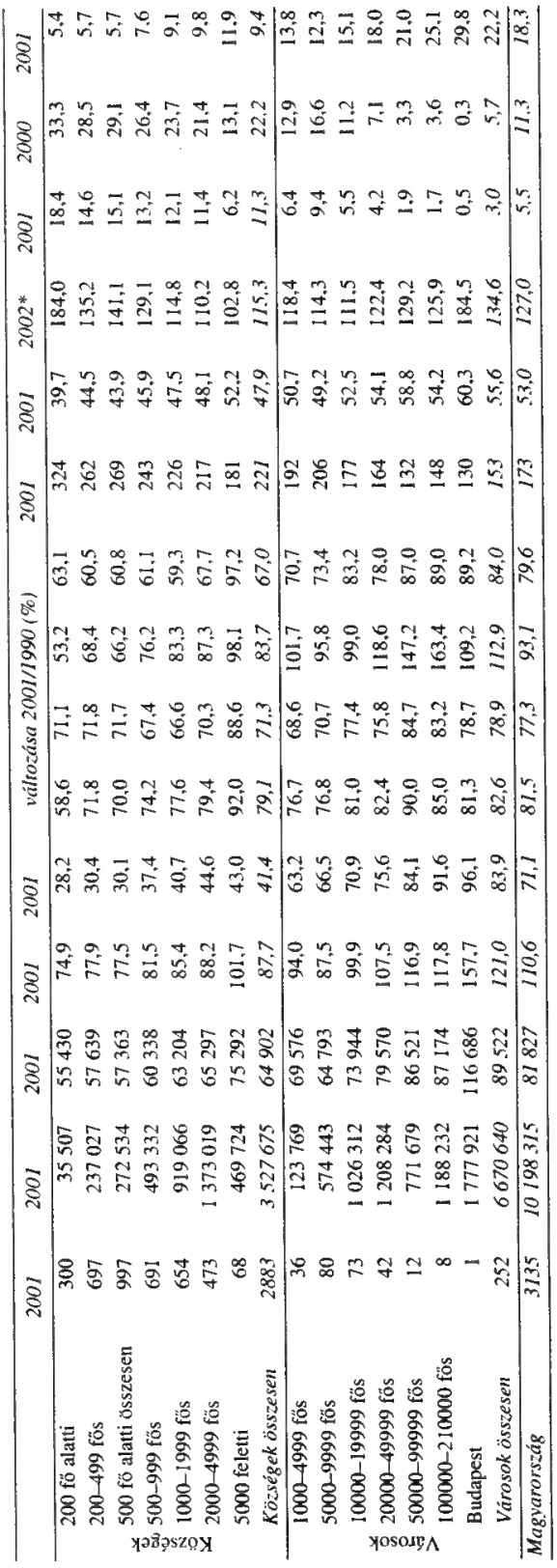


Ami azonban a tanulmány szempontjából központi jelentőségú témakört, a foglalkoztatással kapcsolatos körülmények, illetve a foglalkoztatási képesség alakulását illeti, szemben a demográfiai és népmozgalmi adatokban megmutatkozó „,szabálytalanságokkal", a települési lejtố a várakozásoknak megfelelö szigorúsággal müködik. Részletesebben:

- Bár a legalacsonyabb szinten és jóval átlag alatt maradva, mégis a kistelepüléseken, az 500 fỏnél kisebb lakosságú falvakban nött egyedül a helyben foglalkoztatási kapacitás 1990 és 2001 között (26\%-ról 30\%-ra a gazdaságilag aktív populáció arányában), valószínüsíthetően az önkormányzatok felállásának következtében. A községek átlagában a foglalkoztatottak $41 \%$-a talál helyben munkát, a városokban élők mintegy 84\%-a, míg a hierarchia csúcsán a fővárosiak 96\%-a dolgozhat lakóhelyén lévó munkahelyen.

- A bejárók által betöltött munkahelyek aránya ugyan csökken felfelé haladva a települési lejtőn, de ez a csökkenés nem arányos a helyben foglalkoztatási kapacitással: a városokban a munkahelyek negyedrészét töltik be bejárók (Budapesten az ötödét), a falvak átlagában 30, a legkisebb településeken 38\%-át. Ez föképpen a hierarchia alján elhelyezkedő települési körben következik a helyben rendelkezésre álló munkaeró-kínálat és -kereslet diszkrepanciájából; az ingázási adatok elemzése alapján láthatóvá vált, hogy általában még egy közepes nagyságú város sem képes minden kvalifikált munkakörbe helyi munkaerőt uiltetni és fordítva, megtartani az összes magasan képzett szakembergárdáját. Ennek hatását sejtjük a központok közötti ingázás jelensége mögött.

- Az ingázók száma azokban a településkategóriákban nött, értelemszerüen a nagyobb városokban, ahol egy évtizeddel korábban kifejezetten alacsony volt. Ez különösen jellemző a regionális és megyei hatókörü köżpontokra, kevésbé Budapestre. A városhierarchia alján és a községi hierarchia tetején stabilizálódott az ingázók száma, míg a kisebb lélekszámú községek kategóriáiban a „lejtő" szerint megszabott irányban és ütemben csökkent. Ennek, logikusan, éppen a fordítottja igaz a foglalkoztiiittakra jutó eltartottak és inaktívak számát, továbbá a foglalkoztatott nélküli háztartások arányát jelző mutatószámokra. $A z$ elöregedés, a foglalkoztatottak „visszatorlódása”, ingázási lehetöségek és képességek hiányában fennállo ",avakban rekedése" olvasható ki ezekböl az adatokból. Ez helyenként - a válságövezetekben és a periférikus helyzetü, szegregálódó térségekben - drámai méreteket ölt, az aktív korú népesség arányában vett $70 \%$-ot is meghaladó inaktivitáshoz vezet. ${ }^{8}$

- Vagyis: a legkisebb népességü településkategóriában a legalacsonyabb a foglalkoztatás szintje a 15-64 éves korosztályban, férfiak és nők esetében egyaránt, itt sikerült a legcsekélyebb mértékben csökkenteni a regisztrált munkanélküliek számát 1993, a csúcs, és 2002 között, ezért itt a legmagasabb a munkanélküliségi ráta. Különösen alacsony a női foglalkoztatás $(37 \%$ a 15-64 évesek arányában), míg a férfiak magasabb, 50\%-os foglalkoztatási rátájához magasabb munkanélküliségi ráta társul (13\%). 
S ha az okokra keresünk magyarázatot, azt mondhatjuk, hogy a kistelepülések zömének kedvezötlen helyzetét a periférikus elhelyezkedés, a kis méretekből adódó kereslet- és kínálathiány; az erőforrásokkal, köztük a humán eröforrásokkal való szegényes ellátottság mellett a válságágazatok, mindenekelött a mezögazdaság nagy súlya okozza, úgy a kiinduló helyzet, a kilencvenes évek, mint az ezredforduló vonatkozásában.

Maradva az agrárium fontosságánál: ebben a tekintetben is majdnem kifogástalanul müködik a települési lejtő: az 500 fỏnél kisebb településeken volt a legnagyobb, $40 \%$-os az ágazat foglalkoztatási kapacitása 1990-ben, és 2001-ben is az aprófalusiak dolgoztak a legnagyobb arányban ebben a szektorban, bár már csak $15 \%$-os mértékben, ám itt volt a legmagasabb az egyéni gazdaságok sürüsége is 2000-ben, az Általános Mezőgazdasági Összeírás időpontjában. ${ }^{9}$ A mezőgazdaság, azon belül a kistermelés másodlagos, de a családok megélhetése szempontjából mégis döntő szerepe tehát aligha vitatható.

\section{A csúszdán: gazdasági és társadalmi folyamatok lefelé délnek és keletnek}

Széleskörü egyetértés mutatkozik a szakirodalomban a területi egyenlötlenségek növekedésének ténye, a gazdaságban és társadalomban ható polarizálódási tendenciák súlyossága és mélyreható mivolta tekintetében. ${ }^{10}$ Eszerint a csúszda északról délnek és nyugatról keletnek tart, $\mathrm{s}$ irányváltás aligha várható. Vizsgálatunkban mi sem találtunk mást, a kelet-nyugati és az észak-déli, alapvetően a nagyrégiók között fennálló tagoltság tényét csak megerősíteni tudjuk, a foglalkoztatás tényezöinek alakulását firtató szempontrendszerünk azonban néhány fontos részletre rávilágított, éspedig az alábbiakra:

- A dinamikus központok, illetve ezek hatásainak egymásba érése esetén a dinamikus térségek foglalkoztatásra gyakorolt hatásának önmagukon túlmutató, legalább mezo-térségi, de helyenként annál nagyobb földrajzi térben ható, túlzás nélkül állíthatóan rendkívüli fontossága. Ezt igazolja a 3. ábra: az átlagnál kedvezöbb foglalkoztatási szintủ kistérségek elhelyezkedése mutatja, hogy Budapest, továbbá a Közép- és a nyugat-dunántúli régió dinamikus központjainak foglalkoztatási kapacitása egy folytonos „aktív” (az átlagosnál magasabb gazdasági aktivitást mutató), az országhatár és a fö közlekedési tengelyek mentén "hiperaktív" régió megszületését tette lehetövé az északnyugati ország-negyedben. A gazdasági dinamizmus térségi kisugárzása a foglalkoztatásban képes volt korrigálni a gazdasági átrendeződés következményeit, amely egyes kistérségekben a munkahelyek számának drasztikus visszaesésével járt az érintett régióban is. Az északnyugati ország-negyedtől kis megszakításokkal Szegedig kirajzolódó dinamikus övezet - föként a betelepült transznacionális nagyvállalatok kapcsolatain keresztül - közvetlenül kötődik a nemzetközi hálózatokhoz. ${ }^{11}$ 
- Részben a dinamikus központok erejével, részben a gazdaság térszerkezetének átrendeződésével függ össze a gazdasági szuburbanizáció, amely a Budapesti agglomerációban jelentkezik a legmarkánsabban, és amely létrehozta azt az egyedülálló téregységet a mai Magyarországon, ahol 1990-hez képest szinten maradt a foglalkoztatás $(100,1 \%$ 2001-ben) és parányit ugyan, de növekedett a munkahelyek száma (101,2\%). A 3. ábra kirajzolja azokat a kistérségeket a Budapesti agglomeráción belül, ahol a gazdasági szuburbanizáció mellett a klasszikus, társadalmi értelemben vett kertvárosiasodás folyamata dominál, ahol a városi közép- és felső osztályok kitelepülésének tendenciája markánsan átrendezte a helyi társadalmakat. Ezekben a térségekben úgy átlag felettiek a lakossági jövedelmek, hogy a helyben foglalkoztatottak aránya mélyen átlag alatti (53\%, a $81 \%$-os országos átlaghoz képest.)

- A Budapesti agglomerációt is magában foglaló ingázó övezetek lakosságszámuk növekedése alapján a legdinamikusabban fejlödő téregységeknek tekinthetơk, éspedig nem saját gazdaságuk: míg az ország lakónépességének növekedése 1990 és 2001 között nem érte el az egy százalékot, az ingázó övezetek lakónépessége több mint 137 ezer fövel, hét százalékkal gyarapodott.

- Az ingázás lehetősége tehát esélyt teremt, dinamizáló hatása óriási és a gazdasági klaszterek, sủrüsödési pontok kialakulásának erösödő tendenciájával számolva, feltehetőleg az is marad. Jelentőségét mégsem szabad misztifikálni, mert az ingázást a gazdasági eröviszonyok mellett nagymértékben befolyásolják település-hálózati, térszerkezeti összefuiggések: az Alföldön messze átlag alatti az ingázás intenzitása, látszólag tehát kisebb a központi funkciókkal rendelkező települések vonzereje. Ez abból adódik, hogy-méreteikből adódóan - az alföldi települések helyben foglalkoztatási kapacitása sokkal nagyobb, mint a többi országrész kisfalvakkal övezett kis- és középvárosaié (1. ábra).

- A nyugat-keleti lejtỏ magyarázó ereje mellett az elkészült tipológia hozott néhány, legalább mezo-reoionális szinten fontos eredményt, pontosítást (1. ábra). Ezek között kell meyemlítenünk a válságtérségek lehatárolását, amelyek egyrészről a még ma is markánsan megmutatkozó észak-keleti és dél-nyugati kitermelöipari-nehézipari strukturális válságzónákat, másrészröl a fơként alföldi és dél-dunántúli belsỏ perifériákat foglalják magukba. Az ipari válságtérségek és a depressziós övezetek sorsa mutatja a dinamikus térségekhez, fejlödési gócterïletekhez mért távolság jelentöségét ${ }^{22}$ : míg a középeurópai léptékkel mérhetỏ gócterületek erőterében lévő északnyugatmagyarországi területek iparvidékei többé-kevésbé sikeresen túljutottak a strukturális válságon, ugyanez sem délen, Komló övezetében, sem északon (Ózd, Kazincbarcika, Miskolc térségében) nem sikerült.

- Jóllehet: gazdaságuk meghatározó ágazata alapján vannak markáns vonásokkal jellemezhetô térségi szinten értelmezhető munkaeröpiacok. Ilyenek az összehúzódó, ám továbbra is karakterisztikus mezövárosias térségek az Alföldön, vagy a kisvállalkozások tömegével, magas képzettségủ és magas jövedelmủ munkavállalókkal jellemezhető ,fürdővárosi térségek" a Balaton 
mentén. A zöldmezös beruházásokkal, sikeres privatizációval vagy/és állami reorganizációval megújított ipari térségek mellett ezek képezik az „ágazati” szempontok alapján specifikus kistérségek csoportját.

\section{1. ÁBRA}

Központok típusai és a központba ingázók aránya a 20-59 éves népességben (Types of Centres and Rate of Commuting in the Population Aged 20-59)

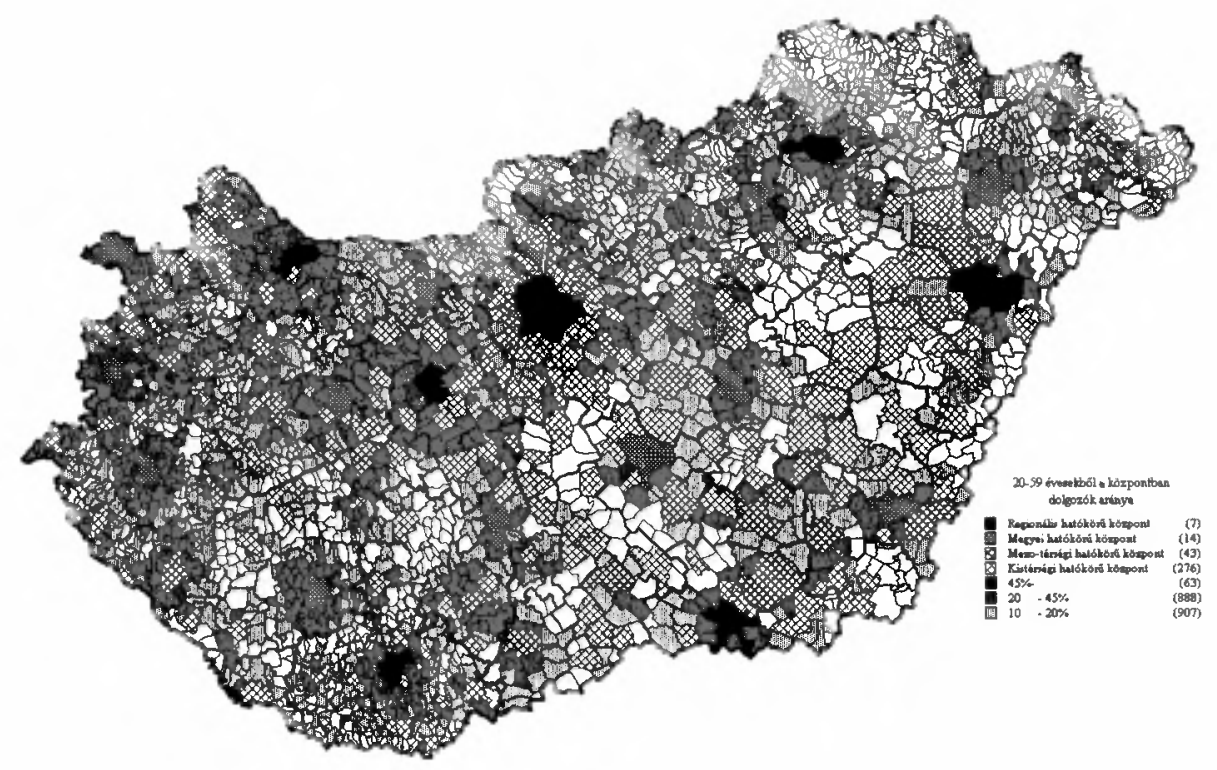

Forrás: KSH Népszámlálás 2001; szerk.: Koós Bálint, MTA RKK KÉTI TKO.

- És végül a „csúszdáról”, amelyen föként az észak-keleti, keleti és déldunántúli megyék külső és belső perifériáin elhelyezkedő kistérségek csúsznak mind lejjebb és lejjebb: nos, ezeket a kistérségeket, szám szerint harmincat, ahol összességében majdnem egymillió ember él, tipológiánkban a „,szegregálódó térségek” elnevezéssel illettük, mert úgy ítéltük meg, hogy $a z$ etnikai szinezetü társadalmi erózió az, amely e térségek közös jellemvonása, és legsúlyosabb problémája. Valamennyi ide tartozó kistérség aprófalvas jellegü, az elcigányosodás, illetve a társadalom peremén élök jelenléte többékevésbé, de mindenütt tetten érhetö e kistérségek nem központi szerepü településeiben. Ugyanakkor nagymértékben különböznek e térségek központjaik erejét, illetve az ingázó távolságban lévö központokhoz mért távolságuk vonatkozásában. Ettől is függ, más tényezöktól is, hogy mekkora mértékü, szórványos, települési szintü vagy kistérségi, esetleg még azon is túlmutató erejü a gettósodás, amely nagyon súlyos társadalmi anomáliák térben koncentrált, társadalmi kirekesztéssel és a falvakba történő visszatorlódással járó, együttes megjelenési formája. 
- A gettósodó falvak azok, ahol a régi és új szegénység ${ }^{13}$ változatos formái uralkodnak, alacsony iskolázottság mellett, 10-20\%-os az aktivitási szint, különösen kismértékủ a női foglalkoztatás, ám nagyon magas az inaktívak aránya és a munkanélküliség, különösen a férfi munkanélküliség (hiszen a nők nem is regisztráltatják magukat), következésképpen nagyon alacsonyak a jövedelmek; ahol a passzivitás uralkodik, mert nines hová eljárni, drága is lenne, és a motiváció is elveszett már, ezért az ingázók száma 1990 és 2001 között majdnem felére esett vissza. Mint a települési lejtö a csúcstól a törpefalvak felé, úgy a foglalkoztatási esélyek tekintetében a regionális csúszda is tökéletes következetességgel müködik a dinamikus központoktól a szegregálódó települések felé.

\section{A kistérségek tipológiája a foglalkoztatási és a társadalomszerkezettel összefüggö szempontrendszer szerint}

A kistérségek munkaerö-piaci helyzetének leírásához demográfiai, aktivitási, ingázási, foglalkoztatás-szerkezeti, vállalkozás-sủrüségi, jövedelmi mutatókat vontunk be az elemzésbe. Összesen mintegy kétszáz változóból és mutatószámból választottuk ki azt a 40-50 mutatót, amelyek segítségével, a központok és „,vidékeik”, vonzáskörzetük jellegzetességei alapján tipizáltuk a kistérségeket, ügyelve arra, hogy a típusok egyben jellegzetes munkaerő-piaci karaktereket képviseljenek. Ezek alapján elóbb egy tizenhat elemủ, majd néhány elem összevonásával egy tízelemủ kategóriarendszerbe soroltuk a kistérségeket. A kategorizálás a kistérség egészének jellegzetességei, a központ (vagy központi funkciójú települések) és „vidékének” kapcsolata, valamint az ingázási viszonyok figyelembe vételével történt (2. táblázat, 2. ábra).

\section{TÁBLÁZAT}

A kistérségek típusai és a népességük alakulása (Types of Micro-regions and the Number of their Populations)

\begin{tabular}{lrcc}
\hline \multicolumn{1}{c}{ Kistérségtípusok } & $\begin{array}{c}\text { Száma } \\
(\mathrm{db})\end{array}$ & $\begin{array}{c}\text { Az ott élök száma } \\
(\text { fö) }\end{array}$ & $\begin{array}{c}\text { Részaránya } \\
(\%)\end{array}$ \\
\hline Budapest & 1 & 1719342 & 17 \\
Regionális és megyei hatókőrü & 18 & 2520498 & 25 \\
központok térségei & 46 & 1943694 & 19 \\
Ingázó övezetbe tartozó kistérségek & 6 & 174028 & 2 \\
Fürdóvárosok és vidékük & 7 & 405009 & 4 \\
Iparvárosok és vonzáskörzeteik & 16 & 918609 & 9 \\
Kompakt középvárosi vonzáskörzetek & 15 & 410329 & 4 \\
Kompakt kisvárosi vonzáskörzetek & 11 & 377922 & 4 \\
Mezővárosias vonzáskörzetek & 18 & 710173 & 7 \\
Depressziós és ipari válságzónák & 30 & 962758 & 9 \\
Szegregálódó térségek & 168 & 10142362 & 100 \\
\hline Összesen & & & \\
\hline
\end{tabular}

Forrás: Népszámlálás 2001, KSH. 


\section{Kistérség-típusok}

A kistérségek típusainak megkülönböztetésekor kiindulópontként arra a besorolásra támaszkodtunk, amely a központok együttes gazdasági ereje, illetve a munkahelyek számából adódó foglalkoztatási kapacitása, továbbá a Beluszky-Györi-féle városhierarchiában ${ }^{14}$ elfoglalt helye ${ }^{15}$ alapján született. A gondunk ezzel a csoportosítással az volt, hogy „középtájon” és a gyenge gazdasági erőt képviselő póluson nagyon különböző karakterú térségeket vont össze. Ezért valamennyi kistérséget a gazdasági aktivitás, a foglalkoztatás ágazati szerkezete, az ingázás intenzitása, a lakossági jövedelem színvonala, a kistérségben élők képzettségi szintje, a kistérség demográfiai, vándorlási jelzőszámai és a központ adatai alapján tekintettünk át, ám szükség szerint más változók alakulását is figyelembe vettük (demográfiai szerkezet és folyamatok). A típusok rövid leírását az alábbiakban közöljük, térbeli megoszlásukat pedig a 2. ábra szemlélteti.

\section{2. ÁBRA}

Gazdasági, munkaerö-piaci és társadalmi indikátorok alapján meghatározott kistérség-típusok Magyarországon (Types of Micro-Regions Based on Economic, Labour Market and Social Indicators)

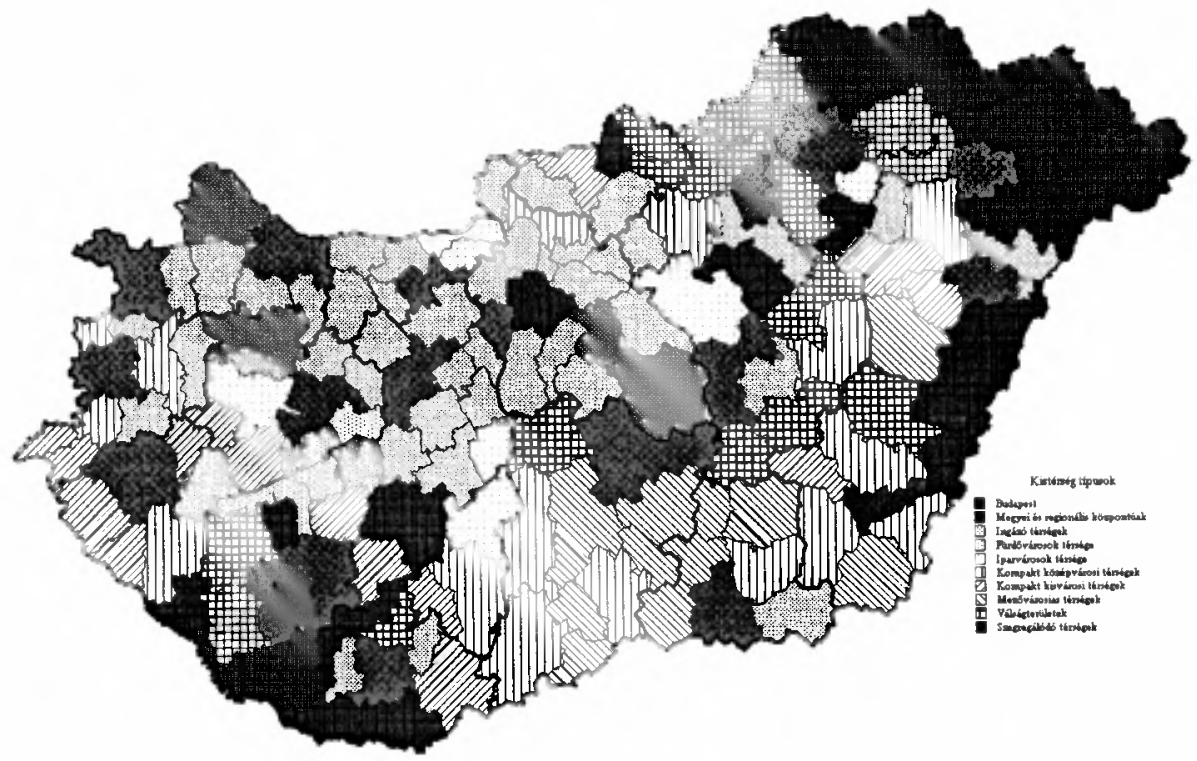

Forrás: KSH Népszámlálás 2001, T-STAR 1990-2001; Szerk.: Koós Bálint, MTA RKK KÉTI TKO.

\section{Budapest}

Budapest Magyarország közép-európai városok között is versenyképes, egyedülálló gazdasági erővel bíró központja. 2001-ben a vállalkozások jegyzett tőkéjének 
46\%-a a fővárosban müködött, a felsőfokú végzettségủ munkavállalók harmada lakott Budapesten, az ország összes munkahelyének közel negyede volt itt található, és több mint 600 településröl mintegy 175 ezer ember kelt naponta útra, budapesti munkahelyére. Óriási az a gazdasági és humán erőforrás koncentráció, amely méltán teszi az ország központjává Budapestet, és emeli a nemzetközileg is versenyképes metropoliszok csoportjába.

\section{Megyei és regionális (hatókörü) központok térségei}

Összesen 18 kistérség 474 települése tartozik e kategóriába. A megyei és regionális hatókörü központokban a munkahelyek száma a kisebbekben 30-50 ezer között, a nagyobbakban 70 ezer felett alakul, magas a képzettségi szint és ennek megfelelỏen alakulnak a jövedelmek és a jóléti mutatók. Akárcsak Budapest, a tőke és a munkahelyek eme nagy koncentrátumait jelentő nagyvárosok is a saját kistérségükön túlnyúló hatókörrel rendelkeznek, bár vonzáskörük földrajzi kiterjedése eltérö, és a bejárók számában is nagy különbségek mutatkoznak közöttük. Közös vonásuk a tőke és a munkahelyek magas koncentrációja, ez biztosítja számukra a kỏzvetlen környezetükön túlnyúló vonzerőt. Erejüket nemcsak a központok, a nagyvárosok saját gazdasági súlya adja, hanem a nagyvárosra épülő, félig-meddig önálló, ugyanakkor a központra is visszaható „agglomerációik” egyre gyarapodó potenciálja is. Tipikus példát nyújt e jelenségre a budapesti agglomeráció néhány gócterülete, elsősorban Budaörs, amely maga is agglomerációs „termék”, ugyanakkor saját környezetében jelentős ingázási célterületté vált, jóllehet valamennyi, a kistérséghez tartozó település elsődlegesen Budapesthez vonzódik, és a tíz település, kettő kivételével, a számottevỏ gazdasági súllyal rendelkezö település (mint Érd, Törökbálint stb.).

Debrecen, Szeged, Pécs, Miskolc hagyományosan a legerősebb centrumtelepülések, ám 2002-re Győr és Székesfehérvár is felzárkózott a legnagyobb, regionális hatókörü központok közé. A megyei hatókörủ központokhoz tartozik a többi megyeszékhely, kivéve Salgótarjánt és Szekszárdot, amelyek alacsonyabb kategóriákba kerültek, helyettük azonban ide nyert besorolást Budaörs és Sopron. Összességében az e csoportba tartozó kistérségekben mủködő vállalkozások jegyzik az országban müködő tőke 22 , a munkahelyek $30 \%$-át, és ezen térségek valamelyikében él a munkavállalók 27\%-a.

\section{Ingázó övezetek}

Az ingázó övezetekhez sorolható 46 kistérség - 697 település és valamivel több, mint 1900 ezer lakos tartozik ide - közös jellemzőjük az átlagosnál magasabb arányú ingázás, ami azonban elsösorban nem a kistérség saját központja, hanem valamely más vonzáscentrum felé irányul. E típus három karakteres alcsoportra osztható.

- Az ingázó kistérségek közül 24-ben a központok viszonylag jelentős gazdasági súllyal rendelkeznek, a kistérség munkaerőpiacának alapvető jellegzetessége 
mégis az, hogy valamely szomszédos megyei hatókörủ, még inkább régiós központba ingázik a munkavállalók jelentős része. (Ilyen a Ceglédi, Dabasi, Szobi kistérség).

- Az elöbbinél gyengébb a pozíciója az ún. ,,második gyürüs ingázó övezeteknek” - 15 kistérség került ebbe a kategóriába -, ahol a saját központ csekély gazdasági súllyal és munkaerö-vonzási képességgel rendelkezik, ezért a munkavállalók egy vagy több, térségen kívüli központba ingáznak, ugyanakkor a népesség gazdasági aktivitása és a bérek viszonylag magasnak mondhatók, és a munkaerő képzettsége is meghaladja az átlagot. Jellemzöen a Budapestet, Székesfehérvárt és Györt övező 20-40 kilométeres körbe tartozó „gyürü” kistérségei tartoznak ebbe a csoportba.

- Sajátos csoportot alkot a budapesti agglomeráció hét kistérsége, ahol az előbbiekkel összevetve is magas az ingázás, a jövedelem és a képzettségi szint. Ezek további közös jellemzöje, hogy a rendszerváltással járó visszaesést követően gazdaságuk megerösödött, olyannyira, hogy ez az egyetlen kategória, ahol a munkahelyek száma - az országos tendenciával szemben - nem csökkent, hanem növekedett!

\section{Iparvárosok térsége}

Az iparvárosokat övező térségek csoportjába hét, meglehetősen erős gazdaságú, kiemelkedő aktivitású, magas jövedelmü, magasan képzett munkaerővel rendelkezö, összesen 199 telepuilést és 400 ezer lakost magában foglaló kistérség tartozik. A rendszerváltással egyidejủleg jelentkező világgazdasági recesszió kisebb-nagyobb mértékben az iparvárosok mindegyikét megrendítette, e térségek azonban sikeresen túlélték az átalakulás időszakát, gazdaságuk és munkaerőpiacuk regenerálódott. Esztergom térségében a Suzuki beruházása adott lendületet a fejlődésnek, Jászberény térségét a sikerrel privatizált Lehel Gépgyár befektetése lendítette túl a mélyponton; a cég mára közép-európai központtá erősödött, és Nyíregyházán nyitja meg következö gyárát. Ajkán az összehúzódott timföldgyártás új piacokra lelt, és ismét talpra állt, az erőmủ sikeresen folytatja tevékenységét, az öntödét francia befektetők privatizálták, a cipögyárat olaszok vették meg, s a megüresedett helyeken olyan új tevékenységek telepedtek meg, mint például a zeolit-gyártás. Tiszaújváros közép-európai szintü összehasonlításban is jelentős vegyipari központ, ahol petrolkémiai termékek előállítása folyik. A paksi atomerömú szinte változatlanul folytathatta tevékenységét, hiszen az ország villamosenergia-fogyasztásának 40\%-át elóállító komplexumot nem érintette jelentősen a gazdasági átalakulás sokkja. A dunaújvárosi ipart annál inkább, de szerencsére az állami szerepvállalással végrehajtott termékszerkezet-váltás a nyomott árak mellett is életképessé tette a termelést. Kevesebb szerencséje volt Dorognak, ahol a bányászat jelentette a fő tevékenységet, $\mathrm{s}$ bár a nagy visszaesést nem tudta elkerülni, a gyorsan megújuló gazdaságú központokba való ingázás révén elkerülte az ipari válságövezetek sorsát. 


\section{Fürdövárosok és vidékük}

Meglehetôsen speciális csoport a fürdővárosokat tartalmazó kistérségeké - a legkisebb lélekszâmú ez a kategória, 174 ezer ember lakik e térségekben -, hiszen a statisztikai adatok szintjén alapvetóen nehéz kimutatni e tevékenységet. A fürdővárosi funkció csak a Balaton mentén elhelyezkedő városokban vált igazán jellegadóvá, más közismert fürdőhelyek adatai ezzel szemben csak színezték a kistérségről kialakított képet. (A Velencét is magában foglaló Gárdonyi és a Bükkel büszkélkedő Csepregi kistérséget például egy hajszál választotta el attól, hogy ebbe a kategóriába soroljuk, fejtörést okozott Gyula és Hajdúszoboszló térsége is.) A fürdőváros-kömyékek sajátos vonása a foglalkoztatási szerkezet eröteljes tercializálódása, a magas aktivitási szint, a csak a legfejlettebb centrumokkal összevethetö mértékü vállalkozói aktivitás, valamint a felsőfokú végzettségüek magas aránya. Jellemzö módon a Balaton-kömyéki kistérségek valamennyien ebbe a csoportba kerültek, a tóparttól távolabb eső központtal rendelkező Tapolcai kistérség kivételével. Az ok nyilvánvaló: csak a Balaton kömyékén nem „szigetszerű”, egy-két (központi) településre korlátozódó a fürdöturizmus. Csak itt élteti térségi és nem kizárólag települési jelleggel vállalkozások sokaságát a mégoly szezonálisan megjelenö nyaralóközönség.

\section{Kompakt középvárosi térségek}

A kompakt középvárosi térségek erős központtal rendelkeznek, $\mathrm{s}$ ha jellemzö is rájuk az ingázás, az a saját centrumba irányul, $s$ kevéssé érvényesül más központok vonzása. A csoportba tartozó 319 ezer lakosú 16 kistérség változatos képet mutat az aktivitás, a foglalkoztatási szerkezet, az ingázás tekintetében egyaránt.

- A viszonylag magas helyi foglalkoztatási kapacitásokkal rendelkezö, ezért alacsony ingázással jellemezhető térségek föként az Alföldröl, a régiós és megyeközpontok közelében fekvő kistérségekböl kerülnek ki (pl. a Bajai, Békési, Gyulai, Hódmezövásárhelyi, Kalocsai kistérségek).

- A magasabb ingázású kompakt középvárosi térségek a Dunántúlon találhatók, ahol egy-egy nagyobb központ mellett kialakult az a közép- és kistelepülési kör, ahonnan elsődlegesen a kistérségi központokba ingáznak a munkavållalók, míg a kistérségi központok aktív korú népességének viszonylag jelentős része a megyeszékhely(ek)en vagy a szomszédos kisvárosokban keres megélhetést. Ez a fajta, vélhetően elsősorban a kvalifikált munkavállalókat érintő „keresztingázás” tipikus dunántúli kis- és középvárosi jelenség, a nagy regionális centrumok felé történő, fentebb bemutatott ingázás regionális válfaja.

\section{Kompakt kisvárosi térségek}

A kompakt kisvárosi térségek rendre valamivel rosszabb mutatókkal bírnak nagyobb gazdasági erővel rendelkező középvárosi társaiknál. Elmaradásuk jelentősnek mondható a jövedelmeket illetően, ám a felsőfokú végzettséggel rendelkezök 
aránya is alacsonyabb az átlagosnál, és a népesség aktivitása is csupán néhány ipari jellegü kistérségben mondható magasnak. E csoportba, 410 ezer lakossal, 15 kistérség tartozik, amelyböl három alföldi és egy Nógrád megyei, a többi jellegzetesen dunántúli aprófalvas környék. Ezek a kisléptékü, mégis szervesnek tünö vonzáskörzetek igazolják, hogy az egészséges kisvárosi gazdaság képes egy viszonylag kicsi térséget is megfelelő kondícióban, életben tartani. (Pl. az Öriszentpéteri, Sümegi, Tapolcai kistérségek.)

\section{Mezövárosias térségek}

Mezővárosiasnak azt a közel 380 ezer ember lakóhelyét jelentö 11 kistérséget neveztük el, amelyeket, elsősorban ma is a mezőgazdaság súlya jellemzi; elsősorban a „vidéki” településeken, de a kistérség központjában (központjaiban) is átlagon felüli az ágazatban foglalkoztatottak aránya. A mezővárosi térségek ugyan hasonlítanak a kompakt kis- és középvárosokhoz, de a kistérségek méretei nagyobbak, ezzel szemben az aktivitás szintje, valamint a jövedelmek itt alacsonyabbak. Az agrárgazdaság összehúzódásával párhuzamosan, az elmúlt évtized során a mezóvárosias kistérségek száma is alaposan megcsappant: 1990-ben még 44 olyan kistérséget találhattunk, ahol a mezógazdaságban foglalkoztatottak aránya meghaladta a 30\%-ot, a 2001. évi adatok alapján azonban már csak 11 kistérséget.

A mezóvárosias kistérségek egytöl egyig az Alföldön találhatók. Bács-Kiskun megye területén a Bácsalmási, Jánoshalmai, Kiskörösi, Kiskunfélegyházi valamint a Kiskunmajsai térségben a szakszövetkezeti forma biztosította a homokos talajon hatékony kertészeti kultưrák és így a gazdálkodási hagyományok továbbélésének lehetöségét, s ez napjainkra egy versenyképes szakmai és piaci ismeretekkel rendelkezö agrárvállalkozói réteg megerösödéséhez vezetett. Csongrád megyében Csongrád, Szentes, Kistelek és Mórahalom környéke jellemezhető mezővárosi karakterrel.

\section{Válságövezetek}

Ez a 18 kistérséget, 308 települést és 710 ezer embert átfogó kategória két tipikus, a részletesebb tipológiában külön besorolású válságterülettel azonos. Az egyik alcsoportot a gazdasági depresszióval, a másikat az ipar strukturális válságával küszködő térségek alkotják. A válságövezetek közös jellemzője azonban, hogy a munkahelyek száma 40\%-kal, a foglalkoztatottak száma egyharmadával esett vissza, az aktivitás szintje nagyon alacsony, mindössze $28,4 \%$.

A gazdasági depresszió sújtotta belsö perifériák (mint Kunszentmárton, Kunszentmiklós, Mezőtúr, Tiszafüred, Szeghalom az Alföldön, Marcali, Nagyatád a Dunántúlon) a regionális és megyei hatókörü városoktól, a dinamizáló erejü gazdasági központoktól egyaránt távol helyezkednek el, egyetlen, gyenge kisvárosi központtal rendelkeznek, és külsô befektetéseket éppen úgy nem tudtak vonzani, ahogy belsô erőforrásaikat sem tudták mobilizálni drámai mértékben összezsugorodott gazdasági kapacitásaik regenerálása érdekében. 
Kitermelö- és nehézipari válságövezetek alkotják az ipari válságtérségeket, amelyek összefüggỏ területet alkotnak a Salgótarján, Eger és Kazincbarcika által határolt iven belül, és ipari depresszió sújtotta kistérségek sorjáznak Miskolc és Nyíregyháza között is. A radikálisan összezsugorodott iparban a megmaradt munkahelyek ugyan megfelelö jövedelmet biztosítanak a foglalkoztatottaknak, ám a tökebefektetéseket nem vonzó gazdaság ereje kevés ahhoz, hogy akár csak a városok környékén élőknek is megfelelő munka- és megélhetési lehetőséget biztosítson. A Dunántúlon ipari válságövezetként csupán a komlói maradt fenn, ahol a bányászat összeomlásával járó válságot a város még nem heverte $\mathrm{ki}$, de a pécsi régióközpontba ingázó térsége ma már jobb helyzetben van, mint maga a központ, Komlo.

\section{Szegregálódó térségek}

Azokat a térségeket neveztük szegregálódónak, ahol az aktivitási, képzettségi és demográfiai adatok elemzése alapján úgy véltük, gettósodási tünetek mutatkoznak, méghozzá az ide sorolt kistérség zömében térségi jelleggel, egy kisebb hányadukban egyelöre csak szétszórtan, néhány településre korlátozódóan. Alacsony aktivitású, nagy gazdasági visszaesést elszenvedett, periférikus helyzetủ térségek tartoznak e csoportba, ahol nagyon alacsony a népesség, főleg a „vidéken” éló népesség képzettsége, magas a munkanélküliség és az inaktivitás minden formája, elenyésző az ingázási arány, és viszonylag fiatal korszerkezet mellett is magas a foglalkoztatott nélküli háztartások aránya. Összesen 30 kistérség tartozik e csoportba, föként az aprófalvas vidékek 725 településének 963 ezer lakója.

A szóban forgó térségek pozíciójának romlását jelzi, hogy míg 1994-ben a vállalkozások jegyzett tőkéjének 3,3\%-a ezekben a kistérségeiben müködött, 2001-ben az itt múködö vállalkozások már csak másfél százaléknyi részesedéssel bírtak. 1990-ben a munkahelyek 9,6\%-a adott megélhetést az itt élöknek, 2001-ben mindössze 7,8\%-ra olvadt a részesedésük. A lakosság havi jövedelmének összege 1994-ben még a vidéki átlag 83 százaléka volt, 2001 -ben már csak 79\%-a. A munkahelyek száma 1990-hez képest 2001-re az országos $77 \%$-kal szemben $63 \%$-ra csökkent, s még ennél is drámaibb, az országos mértéknek majdnem duplája volt a foglalkoztatás visszaesése.

\section{Zárszó}

Ha zárszóként feltesszük a „mi várható és a hogyan tovább” kérdéseit, azt a sejtésünket tudjuk csak az olvasóval megosztani, hogy „sem jobb, sem rosszabb”, vagyis hogy a huszadik század utolsó évtizedében megerösödött térformáló folyamatok intenzitása, hatóereje tovább nő: a befektetôi érdekek továbbra is a megtérülés és a profitszerzés szempontjai szerint formálják a gazdasági teret, $\mathrm{s}$ ez a fejlett régiók további fejlődését eredményezi ${ }^{16}$, a kormányzatnak pedig nem áll módjában a mérleg serpenyöjét kiegyenlíteni, legalábbis nem rövid távon. A relatív távolság a fejlettebb és a fejletlenebb régiók kỏzött jó esetben fennmarad, rossz esetben tovább nő. 
A területi egyenlőtlenségek várható stagnálása, esetleg növekedése, nem feledtetheti a pozitív fejleményeket, így mindenekelött a dinamikusan fejlödő városok, város-együttesek kisugárzó erejét, azt a térségi hatóerőt, amellyel a fejlődés tényezőinek koncentrációja bír. Erre mutat példát most már nemcsak a Budapesti agglomeráció, és nem is csak az északnyugati ország-negyed, hanem a kis hézagokkal ugyan, de Szegedig érö, a globális gazdasági hálózatokba integrált zóna.

A veszteségek listáját megnyitva, valószínüleg nem elkerülhető az alföldi mezővárosias élet- és gazdasági forma további összeszükülése, ami szürkülést hoz majd a színek palettáján, de nem biztos, hogy csak negatív hatásai lesznek. Esélyt ad erre, hogy a Dél-Alföldön tömörülö mezövárosias övezetek nem leromlottak, viszonylag erös gazdaság és nagy méreteikböl adódóan, aránylag kevésbé sérülékeny társadalomszerkezet jellemzi őket.

Végül, de elsősorban: a depressziós térségek, az ipari válságterületek és a szegregálódó perifériák több helyütt egymással összefüggő, rendkívül súlyos és összetett problémarendszerén egy hatékony és innovatív felzárkóztatási politikával lehet csak enyhíteni, éspedig ama kettős cél elérése érdekében, hogy a helyzet ne romoljon tovább, $s$ ha lehet, javuljon, erösítve mind a társadalmi, mind a gazdasági integrációt. Addig is, amíg a határ mentén felélénkülő gazdaság, a szomszédok, tehát a tágabb régió helyzetének javulása ezeket a térségeket is helyzetbe hozza, $\mathrm{s}$ ez nem holnapra várható.

\section{Jegyzetek}

${ }^{1}$ A tanulmány szerzöi köszönetưket fejezik ki Koós Bálintnak az adatok összeállításában nyújtott segítségért és a 2. ábra elkészítéséért.

${ }^{2}$ A tanulmány a „Az esélyegyenlőség jelene és javításának lehetséges módozatai a munkaerö-piaci versenyben, kủlönös tekintettel a hátrányos helyzetü csoportokra" címü, a Foglalkoztatási és Munkaügyi Minisztérium által támogatott, az MTA RKK Térségfejlesztési Kutatások Osztályăn lezajlott kutatás keretében született.

${ }^{3}$ Enyedi (1980) 152-167. o.

${ }^{4}$ Enyedi (1988) 89-96. o.

${ }^{5}$ Ploeg, Jan Jan Douwe at al (2000) 391-408. o.

${ }^{6}$ A településpolitikák kistelepülések fejlödési esélyeire gyakorolt hatásáról Lásd Kovács (1990) és Havas (1999).

${ }^{7}$ Tímár-Váradi (2001)

${ }^{8} \mathrm{Az}$ ingázás kibocsátó és célterületeinek munkanélküliségi rátája és az ingázás költségei közötti összefüggéseket elemzi Köllỏ János egy tanulmánya nyomán Kertesi Gábor, arra a következtetésre jutván, hogy különösen az alacsony iskolai végzettségủek tekintetében elviselhetetlenül nagy esélykülönbség áll fenn a különbözö régiókban az eltérö felvevő képességü és megközelíthetöségü munkaeröpiacokra való eljutás vonatkozásában. Vizsgálatai alapján megállapította, hogy mintegy negyedmillió munkavállalási korú községi lakos számára aránytalanul sokba kerülne az ingázási költségek megfizetése (Kertesi 2000; 793-794). Bartus kiegészíti, illetve valamelyest korrigálja Kertesi megállapításait egy, az ủjra elhelyezkedő volt munkanélkuliek körében folytatott kérdőíves vizsgálat tanulságai alapján. Eszerint feltűnően kevés azoknak az ingázóknak a száma (mintegy 20\%), akik saját költségükre ingáznak. Kertesi megállapítása durván szólva tehát így módosul: olyan drágák az ingázási költségek a munkavállalók $80 \%$-a számára, hogy nem vállalják az ingázást, csak ha költségtérítésben részesülhetnek. Ha ez a feltétel teljesül, akkor azonban mindkét nem esetében $90 \%$-os az ingázási hajlandóság. Másrészt Bartus rámutat arra, hogy fordított összefüggés áll fenn a munkáltatók költségtérítési hajlan- 
Lejtők és csúszdák, avagy a foglalkoztatási esélyek térbeli egyenlötlensége az ezredfordulón. Tér és Társadalom 20. évf. 2006/4. 49-66. p.

dósága és a kistérség munkaeröpiacának jellemzöi között, mivel a munkanélkuliség nagyságával fordí-

${ }^{9}$ Lásd erröl részletesebben G. Fekete (2004). tottan arányos a jó munkaerő megtalálásának valószínủsége (Bartus 2003).

${ }^{10}$ Fazekas (2003), Kiss (2001), Kovács-Koós (2003), Nemes Nagy (2003)

11 Enyedi (2004) 938. 0.

${ }^{12}$ Lásd Nemes Nagy (2003) 139. Tagai térképe

${ }^{13}$ Lásd Ferge (2000) és Spéder (2002)

${ }^{14}$ Beluszky és Györi 2004. A szerzők köszönetüket fejezik ki Beluszky Pálnak a tipologia első változatáról tett segítố megjegyzésejért!

${ }^{15}$ Természetesen nem szerepelt minden, általunk „kỏzpontként” besorolt település a vảroshierarchiában, lévén, hogy községi jogállású települések is szerepelnek a 342 telepullésböl álló csoportban; ezek tipikusan a „csupán kistérségi központ” jogcímen kerültek a rendszerbe, afféle leggyengébb, de létező láncszemként.

${ }^{16}$ Nemes Nagy (2003), Köllő (2003), Fazekas (2003)

\section{Irodalom}

Bajmóczy P.-Dr. Illés T.-Németh E.-Sípos T. (2004) A közösségi közlekedés ellátási rendszerének újragondolása a vidéki (aprófalvas) térségekben. Kézirat. 101.

Bartus T. (2003) Ingázás. - Fazckas Károly (szerk.) Munkaeröpiaci Tükör 2003. MTA Közgazdaságtudományi Kutatóközpont, Országos Foglalkoztatási Közalapítvány, Budapest. 88-101. o.

Beluszky P.-Györi R. (2004) Fel is út, le is út ... - Tér és Társadalom. 1. 1-41. o.

Enyedi Gy. (1980) Falvaink sorsa. Magvetô Kiadó, Budapest.

Enyedi Gy. (1988) A városnövekedés szakaszai. Akadémiai Kiadó, Budapest.

Enyedi Gy. (2004) Regionális folyamatok a poszt-szocialista Magyarországon. - Magyar Tudomány. 9. 935-941. o.

Fazekas K. (2003) A hazai és külföldi tulajdonú vállalkozások területi koncentrációja Magyarországon. Fazekas K. (szerk.) Munkaerópiaci Tikör 2003. MTA Közgazdaságtudományi Kutatóközpont, Országos Foglalkoztatási Közalapítvány, Budapest. 159-171. o,

Ferge Zs. (2000) A társadalom pereme és az emberi méltóság. - Esély 1. 42-48. o.

G. Fekete É. (2004) Munkanélküliség és foglalkoztatási viszonyok az aprófalvas térségekben. Van-e esély a megmaradásra? - A tudomány a gyakorlat szolgálatában. A foglalkoztatási szint bövitésének korlátai és lehetôségei. FMM-MTA, Budapest. 55-85. o.

Havas G. (1999) A kistelepülések és a romák. - Glatz F. (szerk.) A cigányok Magyarországon. MTA Budapest. 163-203. o.

Kertesi G. (2000) Ingázás a falusi Magyarországon. - Közgazdasági Szemle. Október. 775-798. o.

Kiss J.P. (2001) Industrial Mass Production and Regional Differentiation in Hungary. - European Urban and Regional Studies. 4. October. 321-328. o.

Kovács K. (1990) Urbanizáció alulnézetből, Az utóbbi évtizedek társadalomszerkezeti változásai aprófalvas régiókban. - Tóth J. (szerk.) Tér, idö, társadalom. MTA RKK, Pécs. 272-302. o.

Kovács K.-Koós B. (2003) Vidéki kaleidoszkóp. - A falu.Ő́sz. 41-53. o.

Köllö J. (2003) Regionális kereseti és bérköltség-különbségek. - Fazekas K. (szerk.) Munkaeröpiaci Tükör 2003. MTA Közgazdaságtudományi Kutatóközpont, Országos Foglalkoztatási Közalapítvány, Budapest. 65-78. o.

Ladányi J.-Szelényi I. (2004) A kirekesztettség változó formái. Napvilág Kiadó, Budapest.

Nemes Nagy J. (2003) A fekvés és az iskolázottság hatása a területi egyenlötlenségekre Magyarországon. Fazekas K. (szerk.) Munkaeröpiaci Tükör 2003. MTA Közgazdaságtudományi Kutatóközpont, Országos Foglalkoztatási Közalapítvány, Budapest. 133-143. o.

Plet F. (2003) A francia vidék átalakulása és az irányítási formák. - Kovács T. (szerk.) A vidéki Magyarország az EU csatlakozás elött. VI. Falukonferencia. MTA RKK, Pécs. 80-88. o.

Ploeg, J.J.D. (et al.) (2000) Rural Development: from Practices and plocoes towards Theory. Sociologia Ruralis. 40. October. 391-408. o.

Simonyi Á. (szerk.) (2001) Tizenegy falu, ötvenöt család. Kisgyermekes, munkanélküli családok hátrányos munkaerö-piací térségekben. Munkatudományi tanulmányok. Közösen a Jövő Munkahelyeiért Alapítvány, Strukıúra-Munkaügy Kiadó. 
Spéder Zs. (2002) A szegénység változó arcai. Tények és értelmezések. Andorka Rudolf Társadalomtudományi Társaság, Századvég Kiadó.

Tímár J.-Váradi M.M. (2001) The Uneven Development of Suburbanisation during the Transition in Hungary. European Urban and Regional Studies. 4. October. 349-360. o.

Váradi M.M. (2004) Zárványosodó munkaerö-piaci struktúrák és megélhetési stratégiák. - A tudomány a gyakorlat szolgálatában. A foglalkoztatási szint bövitésének korlátai és lehetôségei" c. kiadványban MTA, 35-56. o.

Virág T. (2004) Telepualési hátrány és etnicitás - a gettósodó térség a szegregáció új formaja. Kutatási beszámoló az Encsi kistérségben végzett adatfelvétel alapján. Kézirat.

Williams, C.C.-White, R. (2001) Evaluating the Role of the Social Economy in Tackling Rural Transport Problems: Some Case Study Evidence from Rural England. Planning Practice and Researche. 16. 337-348. o.

\section{SLOPES AND SLIDES: SPATIAL INEQUALITIES IN EMPLOYMENT OPPORTUNITIES AT THE TURN OF THE MILLENIUM}

\section{ZSUZSANNA BIHARI - KATALIN KOVÁCS}

The paper seeks to analyse the vigorous spatial processes of the 1990 , focusing on on-the-spot and distant employment opportunities. The first part examines indicators revealing the social structure of villages on the basis of settlement categories according to population size. The second part reveals the impact zones and integrative abilities of dynamic core areas, towns and cities. This is the basis the typology of statistical micro-regions are built on. Geographical location of settlements, their distance from dynamic centres and the accessibility of such centres were identified as determinants of integrated or peripheral position, absorption capacities as well as employment opportunities of various spatial units. 